\title{
David Oliver: Four riders of the NHS apocalypse
}

\author{
David Oliver consultant in geriatrics and acute general medicine
}

Berkshire

The NHS faces an existential crisis. Last week, four news stories foretold its apocalypse. Think of them as the four horse riders from the Book of Revelation. ${ }^{1}$

On 11 October Chris Hopson, chief of NHS Providers, told the Commons health select committee that England's 44 sustainability and transformation plans (STPs) seemed unrealistic and vastly overambitious, even to their authors. Drafted under excessive pressure, these plans were "at risk of blowing up." "Hopson's earlier written evidence had warned of financial shortfalls and rising demand and costs, making even current service levels unsustainable.

The plans are multi-agency blueprints for localities with an average population of 1.2 million, ${ }^{4}$ promoted by NHS England as vehicles to reconfigure sustainable health and care services and improve patient outcomes, but with a clear focus on delivering savings. ${ }^{5}$ They are newborns, yet initial plans are somehow expected by 21 October.

Notionally, the plans are all about local innovation and leadership, but NHS England bosses have issued heavy handed "planning guidance" and overall financial targets. ${ }^{6}$ Many of the geographical areas were already in serious financial deficit when planning began. ${ }^{7}$

Rider number two galloped in on 13 October, when the Care Quality Commission issued its State of Care report. ${ }^{8}$ Usually inclined to eschew politics or arguing for resources, the CQC broke rank to emphasise that sustained cuts in social care, set out in recent reports from the King's Fund and the National Audit Office, ${ }^{910}$ were now dangerously affecting acute care. The Society for Acute Medicine told the BBC that performance problems this summer rivalled those of last winter. ${ }^{11}$

The third, deeply sinister rider evaded mainstream media, but the Health Service Journal broke the news on 14 October. NHS England had written to leaders instructing them that their plans should ensure that "the public have a good understanding of proposed changes." ${ }^{12}$ Its communications lead, Roger Davidson, reportedly said that plans should explain how they would "strengthen primary care, improve secondary care, achieve success targets and create financial sustainability." ${ }^{12}$ No challenge there, then.
The NHS would receive no additional funding beyond the "additional £10bn" promised

The fourth rider hit the press on 15 October. ${ }^{13}$ The Guardian reported that the bosses of NHS England (Simon Stevens) and NHS Improvement (Jim Mackey) had been told in a private meeting in September with the prime minister, Theresa May, that in the chancellor's autumn statement in November the NHS would receive no additional funding beyond the (widely contested) ${ }^{14}$ "additional $£ 10 \mathrm{bn}$ " it had already been promised in this parliament. This will mean annual increases of $0.6 \%$ or less from 2017-despite rising demand and costs of activity, as well as existing deficits. ${ }^{15}$

In these four stories we see four harbingers of the NHS's last judgment. It's the stuff of nightmares.

Competing interests: See www.bmj.com/about-bmj/freelancecontributors/david-oliver.

Provenance and peer review: Commissioned; not externally peer reviewed.

New World Encyclopaedia. Four horsemen of the apocalypse. www.newworldencyclopedia. org/entry/Four_Horsemen_of_the_Apocalypse.

2 National Health Executive. Over-ambitious STPs are "at risk of blowing-up" because of funding shortfall. 12 Oct 2016. www.nationalhealthexecutive.com/Health-Care-News/overambitious-stps-risk-blowing-up-because-of-scary-funding-shortfall?dorewrite=false.

3 Data.parliament. Written evidence submitted by Chris Hopson, CEO of NHS Providers, to Health Select Committee (FINO003). 6 Oct 2016. http://data.parliament.uk/

writtenevidence/committeeevidence.svc/evidencedocument/health-committee/departmentof-health-and-nhs-finances/written/40440.html.

4 King's Fund. Sustainability and transformation plans (STPs) explained. 24 Aug 2016. www.kingsfund.org.uk/topics/integrated-care/sustainability-transformation-plans-explained.

5 Leys C; Centre for Health and the Public Interest. Can Simon Stevens' sustainability and transformation plans save the NHS? 2016. https://chpi.org.uk/wp/wp-content/uploads/ 2016/05/CHPI-STP-Analysis.pdf.

6 Dunhill L, Hazell W. Planning guidance: "system control totals" to be issued for STPs. Health Serv J 2016 Sep 22. https://www.hsj.co.uk/topics/policy-and-regulation/planning guidance-system-control-totals-to-be-issued-for-stps/7010745.article.

7 Dunhill L. Mapped: the financial health of every STP area. Health Serv J 2016 Sep 22 https://www.hsj.co.uk/topics/finance-and-efficiency/mapped-the-financial-health-of-everystp-area/7004214.article.

8 Care Quality Commission. The state of health care and adult social care in England 2015/16. 15 Oct 2016. www.cqc.org.uk/content/state-of-care.

9 Humphries R, Hall P, Charles A, Thorlby R, Holder H; King's Fund. Home truths: social care for older people. 15 Sep 2016. www.kingsfund.org.uk/publications/social-care-olderpeople.

10 National Audit Office. Department of Health: discharging older patients from hospital. 26 May 2016. https://www.nao.org.uk/wp-content/uploads/2015/12/Discharging-older-patientsfrom-hospital.pdf. 
11 Triggle N. Summer worse than most winters for A\&E. BBC Health News 2016 Oct 13. www.bbc.co.uk/news/health-37634687.

12 Dunhill L. Revealed: NHS England checklist for making STP details public. Health Serv J2016 Oct 14. https://www.hsj.co.uk/topics/service-design/revealed-nhs-england-checklistfor-making-stp-details-public/7011455.article?blocktitle=News\&contentID=15303.

13 Campbell D. No extra money for NHS, Theresa May tells health chief. Guardian 2016 Oct 14. https://www.theguardian.com/politics/2016/oct/14/no-extra-money-for-nhs-theresamay-tells-health-chief.
14 Campbell D. Doctors accuse Tories of deception over "£10bn for NHS" claim. Guardian 2016 Mar 21. https://www.theguardian.com/society/2016/mar/21/bma-doctors-accusetories-lying-extra-10bn-support-nhs-england.

15 Campbell D. BMA: Theresa May lacks understanding of seriousness of NHS crisis. 15 Oct 2016. https://www.theguardian.com/society/2016/oct/15/bma-theresa-may-nhs-crisisautumn-statement.

Published by the BMJ Publishing Group Limited. For permission to use (where not already granted under a licence) please go to http://group.bmj.com/group/rights-licensing/ permissions 